\title{
Granulomatosis with polyangiitis in Northeastern Brazil: study of 25 cases and review of the literature
}

\author{
Francisco Vileimar Andrade de Azevedo ${ }^{1 *}$, Fabrício Oliveira Lima ${ }^{1}$, Jozélio Freire de Carvalho ${ }^{2}$, \\ Andrea Rocha de Saboia Mont'Alverne ${ }^{3}$ and Carlos Ewerton Maia Rodrigues ${ }^{1}$
}

\begin{abstract}
Background: Little has been published about the epidemiology of Granulomatosis with polyangiitis (GPA) in South America, especially in the intertropical zone, and no epidemiological data from Brazil are available. The purpose of the present study was to draw a clinical and demographic profile of GPA patients living in Northeastern Brazil based on laboratory, histological and imaging findings, and evaluate the frequency of organic involvement.

Methods: Clinical, epidemiological and treatment data of GPA patients were collected retrospectively and compared with the literature.

Results: The cohort included 25 GPA patients (84\% female) aged $45.8 \pm 16.1$ years. Renal and ear-nose-throat (ENT) manifestations were the most common (both 64\%). One third (32\%) of the patients had 24-h proteinuria $>1 \mathrm{~g}, 50 \%$ had creatinine clearance $<50 \mathrm{~mL} / \mathrm{min}$ at the time of diagnosis, and $33 \%$ had recurrent kidney damage during disease progress. The affected organs included lungs (60\%), joints (44\%), skin (32\%), peripheral nervous system (28\%), eyes (28\%) and heart (16\%). ENT involvement $(n=16 / 64 \%)$ was less frequent in our region than in São Paulo $(n=115 / 85.8 \%)$. Renal $(n=16 / 64 \%)$ and pulmonary $(n=15 / 60 \%)$ involvement was less frequent in our region than in the U.K. (renal $n=30 / 90 \%$; pulmonary $n=28 / 84.8 \%$ ).

Conclusion: Most of our patients were female, presented the generalized form and were diagnosed late. The frequency of the main clinical manifestations (ENT, renal and pulmonary) was lower than that observed at higher latitudes, suggesting the existence of a Northeast Brazilian clinical and epidemiological profile and adding to our knowledge of this rare condition.
\end{abstract}

\section{Background}

Granulomatosis with polyangiitis (GPA) is a rare systemic disease of the pauci-immune vasculitis spectrum associated with antineutrophil cytoplasmic antibodies (ANCA) [1] and affecting mainly the upper respiratory tract, lungs and kidneys [2]. Approximately $85 \%$ of GPA patients are ANCA-positive, with proteinase 3 (PR3) as the most commonly observed antigen $(\sim 75 \%)[3,4]$.

GPA affects mostly adults, especially Caucasians, with no gender predominance [1]. The mean age at diagnosis is 50 years [5]. GPA is usually treated with a

\footnotetext{
* Correspondence: vileimar@yahoo.com.br

${ }^{1}$ Post-Graduate Program in Medical Sciences, University of Fortaleza (UNIFOR), Fonseca Lobo 560 apto. 1202, Aldeota, Fortaleza, Ceará CEP 60175020, Brazil

Full list of author information is available at the end of the article
}

combination of glucocorticoids and cyclophosphamide, inducing remission in most patients [6]. The recent introduction of rituximab has further increased the rates of remission maintenance $[7,8]$.

The etiology of GPA is unknown, but the frequent early involvement of the upper respiratory tract suggests an environmental cause. Epidemiological studies from the northern hemisphere also support the notion of environmental risk, as reflected in regional differences in prevalence and incidence and the existence of a North-South negative gradient (the incidence of GPA is higher in Northern Europe than in Southern Europe) [5, 9, 10]. Genetic and geographical factors may explain these differences [10-12].

Little has been published about the epidemiology of GPA in South America, especially in the intertropical zone, and no epidemiological data from Brazil are 
available [13-17]. The only two Brazilian studies investigating the clinical and laboratory profile of GPA patients reported a spectrum of clinical manifestations similar to that found in the international literature [13, 14]. However, these Brazilian studies on GPA were conducted outside the intertropical zone [13, 14].

The purpose of the present study was to draw a clinical and demographic profile of GPA patients living in Northeastern Brazil based on laboratory, histological and imaging findings, and evaluate the frequency of organic involvement in relation to data from the international literature.

\section{Methods}

\section{Study design and patient selection}

This descriptive, retrospective and cross-sectional multicenter study was based on medical records covering a period of 10 years (January 2006 to January 2016). The study area was the metropolitan region of Fortaleza, a state capital in Northeastern Brazil located in the intertropical zone $\left(03^{\circ}\right.$ $43^{\prime} \mathrm{S}$ ), with an estimated population just over 4 million [18].

Medical records of patients diagnosed as having "Wegener's granulomatosis", "granulomatosis with polyangiitis", "vasculitis" or International Classification of Diseases (ICD-10) code M31.3 were obtained from three public rheumatology referral centers and from private clinics located in the metropolitan region of Fortaleza to which GPA patients are referred for evaluation. The medical records were reviewed by a single investigator (FVAA). Ambiguous cases were discussed by two rheumatologists (CEMR and FVAA) until reaching a consensus. Two patients did not meet the clinical diagnostic criteria for GPA and were excluded.

To be eligible, patients had to be living in the metropolitan region of Fortaleza and meet the criteria of the classification algorithm of the European Medicines Agency (EMA) [19].

\section{Data collection}

The information retrieved from medical records included demographic data, comorbidities, disease extension (localized / early systemic / generalized / severe / refractory) [20], clinical manifestations (including signs and symptoms at diagnosis and during the course of the disease), treatment and histopathological, radiologic and laboratory findings. The clinical parameters and definitions of organ involvement were based on the Birmingham Vasculitis Activity Score (BVAS; version 3 ) and were actively searched for in the medical records [21].

The following clinical parameters were actively searched for:

- Upper respiratory tract: rhinorrhea, crusting, nosebleed, oral and nasopharyngeal ulceration, chronic sinusitis, otitis media, saddle nose deformity, mastoiditis, hearing loss and subglottic stenosis.
- Lungs: hemoptysis, alveolar hemorrhage, respiratory failure and pulmonary infiltrates (in the absence of concurrent infection), nodules or cavitations.

- Kidneys: fall in creatinine clearance $>25 \%$, proteinuria $>500 \mathrm{mg} /$ day, hematuria or red blood cell casts in urinary sediment.

- Joints: arthritis, polyarthralgias or morning stiffness for $>1 \mathrm{~h}$.

- Skin: petechiae or purpura, nodules, skin vasculitis and skin ulcers.

- Eyes: conjunctivitis, episcleritis, scleritis, pseudotumor, amaurosis.

- Nervous system: peripheral neuritis, cranial neuropathy, pachymeningitis or CNS vasculitis.

- Heart: valvular lesions, pericarditis, myocarditis, conduction system abnormalities.

- Gastrointestinal tract: mesenteric vasculitis, bloody diarrhea, colitis.

The laboratory data included complete blood count, serum creatinine, urine analysis, 24-h urine protein output and immunological markers (ANCA and PR3/MPO). ANCA was detected by indirect immunofluorescence with ethanol-fixed neutrophils and specificity for PR3-ANCA and MPO-ANCA was determined by ELISA. The tests were carried out at two core laboratories. Creatinine clearance was estimated using the equation developed by the Chronic Kidney Disease Epidemiology Collaboration (CKD-EPI) [22]. Peripheral nervous system involvement was diagnosed based on electroneuromyographic changes. The histopathological examination was considered positive when findings were compatible with vasculitis with granulomatous changes, or necrotizing vasculitis, or pauci-immune necrotizing glomerulonephritis.

Limited GPA was diagnosed in cases with symptoms limited to a single organ and without kidney involvement. The extension of organ injury secondary to GPA was quantified with the Vasculitis Damage Index (VDI) based on the most recent medical appointment [23]. Disease activity at the time of diagnosis was quantified with the Birmingham Vasculitis Activity Score (BVAS, v.3) [21].

The evaluation of comorbidities included information on systemic arterial hypertension, thyroid pathologies, diabetes mellitus and obesity.

Refractoriness to treatment was defined as progressive decline in kidney function with active urine sedimentation and persistence of (or the appearance of new) extrarenal manifestations. Relapse was defined as post-remission recurrence of signs and symptoms of active vasculitis in any organ [24].

\section{Statistical analysis}

The prevalence was calculated by dividing the number of GPA patients on 31 January 2016 by the population of the metropolitan region of Fortaleza in 2016, as estimated 
by the Brazilian Institute of Geography and Statistics. Demographic and clinical parameters were expressed as mean values \pm standard deviation (continuous variables) and frequencies and percentages (categorical variables). Non-normally distributed continuous variables were expressed as median values (maximum and minimum). The clinical, epidemiological and laboratory data were collected and managed with a standardized instrument, creating a database with individual patient entries. Microsoft Excel@ spreadsheets were used for descriptive statistics.

The study protocol was approved by the Research Ethics Committee of the University of Fortaleza (Unifor) and by the IRBs of the three participating referral centers.

\section{Results}

\section{Patient characteristics and demographic profile}

The demographic and clinical characterisitics of the 25 GPA patients included in the study are shown in Table 1. Caucasians accounted for $28 \%$. The disease extension was predominantly generalized (52\%). Twelve percent of the patients were classified as "severe extension" and $20 \%$ as "localized disease". Time between the onset of clinical manifestations and diagnosis varied greatly, and diagnosis took over 6 months to be established in $46 \%$. The 2016 prevalence of GPA the metropolitan region of Fortaleza was estimated at 5.0/1,000,000 pop.

As for comorbidities at the time of diagnosis, $40 \%$ were receiving treatment for systemic arterial hypertension, one patient had Hashimoto's thyroiditis and one had type- 2 diabetes mellitus. A summary of the demographic, clinical and laboratory data is presented in Table 1.

\section{Clinical manifestations}

Renal and ENT involvement were the most common manifestations in our cohort $(n=16 / 64 \%)$. The type and frequency of the clinical manifestations at presentation and/or during the course of the disease are shown in Table 2.
Nephritic syndrome was the most frequent manifestation (52\%) among patients with renal impairment. The lungs were affected in 15 patients $(60 \%)$. One patient had a chest CT displaying bibasilar pulmonary infiltrate with tree-in-bud sign suggestive of pulmonary fibrosis with honeycombing.

\section{Laboratory and anatomopathological findings}

Most patients (88\%) were ANCA-positive (c-ANCA 91\%; p-ANCA 9\%). Anti-PR3 ELISA was only performed on 4 patients, yielding $100 \%$ positivity. At diagnosis, the median ANCA titer on immunofluorescence was 1:320 (range: 20-640), the median 24-h urine protein output was $858 \mathrm{mg}$ (range: $56-26,350$ ) and the mean hemoglobin level was $11.3 \pm 2.5 \mathrm{~g} / \mathrm{dL}$.

Biopsies were taken from 15 patients: four skin biopsies revealing leukocytoclastic vasculitis $(n=3)$ and Churg Strauss granuloma $(n=1)$, four kidney biopsies revealing pauci-immune crescentic glomerulonephritis $(n=1)$, focal segmental glomerulosclerosis $(n=1)$, diffuse proliferative glomerulonephritis $(n=1)$ and acute tubular necrosis $(n=1)$, two bronchial biopsies revealing granulomatous vasculitis, two pulmonary nodule biopsies revealing granulomatous vasculitis with organizing pneumonia, two nasal mucosa biopsies revealing granulomatous vasculitis, and one sural nerve biopsy revealing granulomatous vasculitis.

\section{Frequency of clinical manifestations: Northeastern Brazil vs. other regions}

Tables 3 and 4 show the frequency of clinical manifestations observed in the present study (Northeastern Brazil) and in studies from the northern and southern hemispheres.

- ENT involvement was less frequent in Northeastern Brazil $(n=16 ; 64 \%)$ than in São Paulo $(n=115$; $85.8 \%)$ and New Zealand $(n=63 ; 86 \%)[11,13]$.

Table 1 Demographic, clinical and laboratory data of a cohort of 25 patients from Northeastern Brazil diagnosed with granulomatosis with polyangiitis (GPA) between 2005 and 2016

\begin{tabular}{lc}
\hline Demographic, clinical and laboratory variables & $n=25$ \\
\hline Female gender (\%) & 84 \\
Months from diagnosis to present age, median (range) & $45(1-120)$ \\
ANCA positivity (\%) & 88 \\
Months from onset of manifestations to diagnosis, median (range) & $6(1-192)$ \\
Biopsy performed (\%) & 60 \\
Rate of biopsies positive for granuloma (\%) & 47 \\
BVAS score at diagnosis, median (range) & $6(2-16)$ \\
VDI score, median (range) & $4(0-12)$ \\
\hline ANCA antin
\end{tabular}

ANCA antineutrophil cytoplasmic antibodies, BVAS Birmingham vasculitis activity score, VDI vasculitis damage index. Results expressed as mean values \pm standard deviation, percentages or median values (maximum and minimum) 
Table 2 Frequency of clinical manifestations in 25 patients from Northeastern Brazil diagnosed with granulomatosis with polyangiitis (GPA) between 2005 and 2016

\begin{tabular}{|c|c|c|c|}
\hline Organ/system $(n=25)$ & n (\%) & Clinical manifestation & n (\%) \\
\hline \multirow[t]{7}{*}{ Kidney } & $16(64)$ & Nephritic syndrome & $13 / 16(81)$ \\
\hline & & Creatinine clearance $<50 \mathrm{~mL} / \mathrm{min}$ at diagnosis & $12 / 16(75)$ \\
\hline & & Microscopic hematuria at presentation & $12 / 16(75)$ \\
\hline & & Proteinuria $>1 \mathrm{~g} /$ day $(\mathrm{mg} / 24 \mathrm{~h})$ & $8 / 16(50)$ \\
\hline & & Proteinuria $>1 \mathrm{~g} /$ day $(\mathrm{mg} / 24 \mathrm{~h})$ at presentation & $6 / 16(38)$ \\
\hline & & Nephrotic-range proteinuria & $5 / 16(31)$ \\
\hline & & Chronic kidney disease requiring dialysis & $4 / 16(25)$ \\
\hline \multirow[t]{3}{*}{ Nose, ear, throat } & $16(64)$ & Sinusitis & 15/16 (93) \\
\hline & & Sensorineural deafness & $3 / 16(18)$ \\
\hline & & Mastoiditis & 2/16 (13) \\
\hline \multirow[t]{3}{*}{ Lung } & $15(60)$ & Pulmonary nodule & $7 / 15(47)$ \\
\hline & & Alveolar hemorrhage & $4 / 15(27)$ \\
\hline & & Bronchial stenosis & 2/15 (13) \\
\hline \multirow[t]{2}{*}{ Constitutional manifestations } & $12(48)$ & Fever & $9 / 12(75)$ \\
\hline & & Asthenia & $2 / 12(17)$ \\
\hline Joints & $11(44)$ & Oligo/polyarthritis & $11 / 11(100)$ \\
\hline \multirow[t]{2}{*}{ Skin } & $8(32)$ & Purpura of lower limbs & $8 / 8(100)$ \\
\hline & & Churg-Strauss nodule & $1 / 8(13)$ \\
\hline \multirow[t]{3}{*}{ Peripheral nervous system } & $7(28)$ & Axonal polyneuropathy & 4/7 (57) \\
\hline & & Multiple mononeuritis & 2/7 (28) \\
\hline & & Facial nerve paralysis & $1 / 7(14)$ \\
\hline \multirow[t]{4}{*}{ Eyes } & $7(28)$ & Orbital pseudotumor & $3 / 7(42)$ \\
\hline & & Scleritis & $3 / 7(42)$ \\
\hline & & Conjunctivitis & 2/7 (28) \\
\hline & & Uveitis & $1 / 7(14)$ \\
\hline \multirow[t]{3}{*}{ Heart } & $4(16)$ & Mitral insufficiency & $2 / 4(50)$ \\
\hline & & Congestive heart failure & $1 / 4(25)$ \\
\hline & & Third-degree atrioventricular block & $1 / 4(25)$ \\
\hline Central nervous system & $1(4)$ & Transverse myelitis & $1 / 1(100)$ \\
\hline Gastrointestinal tract & $1(4)$ & Bloody diarrhea & $1 / 1(100)$ \\
\hline
\end{tabular}

- Pulmonary involvement was less frequent in Northeastern Brazil $(n=15 ; 60 \%)$ than in the U.K. $(n=28 ; 84.8 \%)$ [25].

- Renal involvement was less frequent in Northeastern Brazil $(n=16 ; 64 \%)$ than in the U.K. $(n=30 ; 90 \%)$ [25].
Treatment

All 25 patients received corticosteroids as first-line therapy. Treatment for GPA consisted of a combination of corticosteroids and cyclophosphamide in $56 \%$ of the patients. All patients received intravenous cyclophosphamide

Table 3 Frequency of clinical manifestations in patients with granulomatosis with polyangiitis (GPA) from Northeastern Brazil (present study) and other countries in the southern hemisphere

\begin{tabular}{lllll}
\hline $\begin{array}{l}\text { Organ/system involved } \\
\text { n (\%) }\end{array}$ & $\begin{array}{l}\text { Northeastern Brazil } \\
\text { (present study) }\end{array}$ & $\begin{array}{l}\text { Southeastern Brazil } \\
\text { (Souza et al., [13]) }\end{array}$ & Chile (Cisternas et al., [15]) & $\begin{array}{l}\text { New Zealand } \\
\text { (Gibson et al., [1 1]) }\end{array}$ \\
\hline Number of patients & 25 & 134 & 58 & 73 \\
ENT symptoms & $16(64 \%)$ & $115(85.8 \%)$ & $33(57 \%)$ & $63(86 \%)$ \\
Lung involvement & $15(60 \%)$ & $104(77.6 \%)$ & $36(62 \%)$ & $38(52 \%)$ \\
Renal involvement & $16(64 \%)$ & $101(75.4 \%)$ & $45(78 \%)$ & $57(78 \%)$ \\
\hline
\end{tabular}


Table 4 Comparison of frequency of clinical manifestations in patients with granulomatosis with polyangiitis (GPA) from Northeastern Brazil (present study) and from three countries in the northern hemisphere

\begin{tabular}{lllll}
\hline $\begin{array}{l}\text { Organ/system involved } \\
\mathrm{n}(\%)\end{array}$ & Northeastern Brazil (present study) & U.K. (Fujimoto et al., [25]) & Japan (Fujimoto et al., [25]) & Italy (Catanoso et al., [10]) \\
\hline Number of patients & 25 & 33 & 8 & 18 \\
ENT symptoms & $16(64 \%)$ & $28(85 \%)$ & $8(100 \%)$ & $10(55.6 \%)$ \\
Lung involvement & $15(60 \%)$ & $28(85 \%)$ & $3(38 \%)$ & $10(55.6 \%)$ \\
Renal involvement & $16(64 \%)$ & $30(90 \%)$ & $3(38 \%)$ & $10(55.6 \%)$ \\
\hline
\end{tabular}

in monthly pulses. Azathioprine was the drug most frequently used for maintenance (36\%). Due to pulmonary-renal syndrome, $1(4 \%)$ patient had plasmapheresis and 1 (4\%) required immunoglobulin therapy. Nine (36\%) were treated with rituximab: 4 due to glomerulonephritis refractory to cyclophosphamide, 1 due to recurrence of renal activity after one year of maintenance with azathioprine, 2 due to alveolar hemorrhage, 1 due to orbital pseudotumor and 1 due to sensory axonal polyneuropathy. The last four patients were refractory to cyclophosphamide therapy or presented recurrent infection during immunosuppression (Table 5).

\section{Adverse events and mortality}

Infections requiring hospitalization included 2 cases of recurrent pneumonia, 1 case of recurrent pyelonephritis and 1 case of lung abscess. No patient presented Pneumocystis jirovecii pneumonia or active tuberculosis, but 2 had a history of tuberculosis treated more than five years before GPA diagnosis.

Seven (28\%) of the 25 patients presented new onset or worsening of systemic arterial hypertension and one patient developed diabetes mellitus after GPA diagnosis. Two developed osteoporosis, one of whom with pathological fracture.

Within the study period, 4 deaths were confirmed. Two occurred within one year after diagnosis due to severe pulmonary hemorrhage and rapidly progressing glomerulonephritis (pulmonary-renal syndrome), and 2 occurred years after diagnosis, due to diffuse alveolar hemorrhage in dialytic patients. The 5-year and 10-year mortality rate was 10 and $22 \%$, respectively. The ability of BVAS scores at diagnosis to predict mortality was evaluated, however no association was observed between BVAS score and fatal outcome. BVAS > 6: (dead: $n=1$; alive: $n=9)$; BVAS $\leq 6$ : (dead: $n=3$; alive: $n=12)(p=0.627)$.

\section{Discussion}

This is the largest retrospective multicenter study to draw a clinical and epidemiological profile of patients with GPA from Northeastern Brazil and the first to systematically use BVAS and VDI scores. Compared to the international literature, the upper respiratory tract and the lungs were less frequently affected in our patients from Northeastern Brazil [11, 13, 25]. The most frequent disease extension was generalized, and time to diagnosis was relatively long (in one case, 18 years from the onset of symptoms).

Our sample was predominantly female (84\%; M/F ratio: 0.2). Gender distribution is known to be influenced by geographical variables [10]. For example, the female gender was predominant in a study from Southern Europe while the male gender was predominant in a study from Northern Europe $[5,10]$. Within the southern hemisphere, the male gender is predominant in New Zealand $\left(43^{\circ} \mathrm{S}\right)$ (M/F ratio: 1.2 ) and Argentina $\left(31^{\circ} \mathrm{S}\right)(\mathrm{M} / \mathrm{F}$ ratio: 1.2$)$, while the female gender is predominant in Chile $\left(33^{\circ} \mathrm{S}\right)$ (M/F ratio: 0.8$)$ and São Paulo $\left(23^{\circ} \mathrm{S}\right)(\mathrm{M} / \mathrm{F}$ ratio: 0.9$)$ $[11,13,15,16]$. In short, available data suggest a tendency for female predominance among GPA patients at low latitudes in both hemispheres [10].

The average age at diagnosis in the present study (42 years) was similar to that observed in studies from São Paulo (43.4 years) and the U.S. (41 years) [1, 13], but GPA patients from Chile (50.8 years), Australia (55 years), New Zealand (66 years) and Italy (58.8 years) were significantly older $[10,11,15,26]$, possibly due to differences in geographical variables and/or in methodology. In fact, populational studies suggest GPA is more frequent in older individuals whereas case studies conducted at hospitals show a lower age at diagnosis [5, 27, 28].

Matching the literature, ENT was the most frequently involved organ system, followed by the lung $[1,5,10]$. The most frequent pulmonary manifestation was pulmonary nodules, as observed in other studies conducted in the southern hemisphere $[11,13]$. Sinus disorder was the main manifestation of ENT involvement observed, but the frequency was still significantly lower in our study than in studies from Southeastern Brazil and New Zealand $[11,13]$. The observed prevalence of skin involvement $(32 \%$, all of which included purpura) was comparable to that reported in another Brazilian study and in studies conducted in the northern hemisphere. With a frequency of less than $30 \%$, PNS involvement (predominantly axonal polyneuropathy) was within the range reported worldwide [1, 13, 29]. Ocular involvement was less frequent in Northeastern Brazil $(n=1 ; 4 \%)$ than in New Zealand $(n=15 ; 20 \%)$ [11]. 
Table 5 Clinical, histopathological, therapeutic, evolutional, therapeutic and laboratory data of 25 patients from Northeastern Brazil diagnosed with granulomatosis with polyangiitis (GPA) between 2005 and 2016

\begin{tabular}{|c|c|c|c|c|c|c|c|}
\hline Patient & Sex & $\begin{array}{l}1 \mathrm{stM} \rightarrow \mathrm{D} \\
\text { (months) }\end{array}$ & Clinical manifestations & $\begin{array}{l}\text { Current } \\
\text { 24-h UPO }\end{array}$ & ANCA & Biopsy & Therapy \\
\hline 1 & $\mathrm{~F}$ & 6 & nephritic syndrome, hemoptysis, CKD & 1461 & c-Anca + Tu & $n / a$ & CS, CFM \\
\hline 2 & $\mathrm{~F}$ & 1 & $\begin{array}{l}\text { Hemoptysis, nephritic syndrome, AKI, } \\
\text { purpura, sinusitis, mastoiditis, acral necrosis }\end{array}$ & 816 & c-Anca + 1:80 & $\mathrm{n} / \mathrm{a}$ & CS, CFM \\
\hline 3 & $\mathrm{~F}$ & 3.5 & $\begin{array}{l}\text { sinusitis, scleritis, multiple mononeuritis, } \\
\text { pulmonary nodule, polyneuropathy, CHF, } \\
\text { nephritic syndrome; AKI }\end{array}$ & 3760 & $c-A n c a+T u$ & $\begin{array}{l}\text { Pulmonary nodule: } \\
\text { granulomatous } \\
\text { vasculitis with OP }\end{array}$ & CS, CFM, RTX \\
\hline 4 & M & 6 & $\begin{array}{l}\text { laryngitis, sinusitis, pulmonary nodule, } \\
\text { hemoptysis, upper respiratory tract stenosis }\end{array}$ & 150 & c-Anca + 1:320 & $n / a$ & CS, CFM, RTX \\
\hline 5 & $\mathrm{~F}$ & 66 & $\begin{array}{l}\text { sinusitis, polyarthritis, purpura laryngitis, } \\
\text { bronchial stenosis }\end{array}$ & 130 & c-Anca - & Skin: LCV & CS, CFM \\
\hline 6 & $\mathrm{~F}$ & 0.5 & sinusitis, CKD, alveolar hemorrhage, death & $\mathrm{n} / \mathrm{a}$ & c-Anca $+1: 640$ & $n / a$ & CS, CFM \\
\hline 7 & $\mathrm{~F}$ & 84 & $\begin{array}{l}\text { sinusitis, polyarthritis, saddle nose deformity, } \\
\text { pulmonary nodule }\end{array}$ & 74 & c-Anca - & $\begin{array}{l}\text { Nasal mucosa: } \\
\text { granulomatous } \\
\text { vasculitis }\end{array}$ & CS \\
\hline 8 & $\mathrm{~F}$ & 36 & $\begin{array}{l}\text { multiple mononeuritis, transverse myelitis, } \\
\text { neurosensory deafness, sinusitis, uveitis, } \\
\text { polyarthritis, polyneuropathy, laryngitis, } \\
\text { pulmonary nodule }\end{array}$ & 150 & c-Anca - & $n / a$ & CS, CFM, RTX \\
\hline 9 & $\mathrm{~F}$ & 216 & $\begin{array}{l}\text { sinusitis, saddle nose deformity nephritic } \\
\text { syndrome, polyarthritis, dialytic AKI }\end{array}$ & $\mathrm{n} / \mathrm{a}$ & c-Anca + 1:40 & $\mathrm{n} / \mathrm{a}$ & CS \\
\hline 10 & $\mathrm{~F}$ & 12 & $\begin{array}{l}\text { neurosensory deafness, polyarthritis, } \\
\text { nephrotic syndrome, nephritic syndrome, } \\
\text { epistaxis, dialytic CKD, alveolar hemorrhage, } \\
\text { death }\end{array}$ & 385 & c-Anca + 1:160 & n/a & CS, AZA, RTX \\
\hline 11 & M & 120 & $\begin{array}{l}\text { polyarthritis, purpura; sinusitis, orbital } \\
\text { pseudotumor, otitis media, pericardial effusion }\end{array}$ & 64 & $c-A n c a+T u$ & $\mathrm{n} / \mathrm{a}$ & CS, AZA, RTX \\
\hline 12 & $\mathrm{~F}$ & 0.5 & $\begin{array}{l}\text { polyarthritis, nephritic syndrome; epistaxis, } \\
\text { mastoiditis, scleritis, pulmonary nodule, } \\
\text { facial nerve paralysis, CKD, mitral insufficiency }\end{array}$ & 1680 & c-Anca + 1:160 & $\begin{array}{l}\text { Bronchial lesion: } \\
\text { granulomatous } \\
\text { vasculitis }\end{array}$ & $C S, A Z A$ \\
\hline 13 & M & 5 & $\begin{array}{l}\text { neurosensory deafness, polyneuropathy, } \\
\text { polyarthritis, purpura, acral necrosis, nephritic } \\
\text { syndrome; pulmonary nodule }\end{array}$ & 150 & c-Anca + 1:640 & $\begin{array}{l}\text { Sural nerve: } \\
\text { granulomatous } \\
\text { vasculitis }\end{array}$ & $C S, A Z A$ \\
\hline 14 & $\mathrm{~F}$ & 5 & $\begin{array}{l}\text { neurosensory deafness, sinusitis, nephritic } \\
\text { syndrome, pulmonary nodule }\end{array}$ & 1078 & c-Anca + 1:40 & $\begin{array}{l}\text { Kidney: diffuse } \\
\text { proliferative GN }\end{array}$ & CS, CFM \\
\hline 15 & $\mathrm{~F}$ & 192 & $\begin{array}{l}\text { scleritis, polyarthritis, epistaxis, orbital } \\
\text { pseudotumor, sinusitis, hemoptysis, AKI, } \\
\text { amaurosis }\end{array}$ & 511 & p-Anca + 1:640 & $\begin{array}{l}\text { Kidney: acute } \\
\text { tubular necrosis }\end{array}$ & CS, CFM \\
\hline 16 & $\mathrm{~F}$ & 42 & $\begin{array}{l}\text { nodular scleritis, neurosensory deafness, } \\
\text { polyarthritis, pulmonary nodule, third-degree } \\
\text { AVB, cutaneous nodule }\end{array}$ & 200 & c-Anca + 1:640 & $\begin{array}{l}\text { Skin: Churg-Strauss } \\
\text { granuloma; pulmonary } \\
\text { nodule: granulomatous } \\
\text { vasculitis with OP }\end{array}$ & CS, CFM \\
\hline 17 & $\mathrm{~F}$ & 120 & $\begin{array}{l}\text { Purpura, hemoptysis, cutaneous nodule, } \\
\text { polyarthritis, CKD, orbital pseudotumor, }\end{array}$ & 900 & c-Anca + 1:320 & $\begin{array}{l}\text { Nasal mucosa: } \\
\text { granulomatous } \\
\text { vasculitis }\end{array}$ & CS, CFM, AZA, RTX \\
\hline 18 & $\mathrm{~F}$ & 0.5 & purpura, pulmonary-renal syndrome, death & $\mathrm{n} / \mathrm{a}$ & c-Anca + 1:320 & Skin: LCV & CS, IMGN \\
\hline 19 & M & 1 & $\begin{array}{l}\text { polyarthritis, nephrotic syndrome, } \\
\text { pulmonary-renal syndrome, death }\end{array}$ & 26,350 & c-Anca + 1:80 & $\begin{array}{l}\text { Bronchial: } \\
\text { granulomatous } \\
\text { vasculitis }\end{array}$ & CS, CFM, PLASMF \\
\hline 20 & $\mathrm{~F}$ & 1 & $\begin{array}{l}\text { sinusitis, purpura, polyarthritis, nephritic } \\
\text { syndrome }\end{array}$ & 775 & c-Anca + 1:640 & Kidney: FSGS & CS, CFM, RTX \\
\hline 21 & $\mathrm{~F}$ & 120 & hemoptysis, otitis media, sinusitis & 140 & c-Anca + 1:640 & $n / a$ & $\mathrm{CS}, \mathrm{AZA}, \mathrm{RTX}$ \\
\hline 22 & $\mathrm{~F}$ & 32 & $\begin{array}{l}\text { Raynaud phenomen, vertigo, } \\
\text { polyneuropathy, purpura, sinusitis }\end{array}$ & 150 & c-Anca + 1:20 & Skin: LCV & $C S, A Z A$ \\
\hline
\end{tabular}


Table 5 Clinical, histopathological, therapeutic, evolutional, therapeutic and laboratory data of 25 patients from Northeastern Brazil diagnosed with granulomatosis with polyangiitis (GPA) between 2005 and 2016 (Continued)

\begin{tabular}{|c|c|c|c|c|c|c|c|}
\hline Patient & Sex & $\begin{array}{l}1 \text { stM } \rightarrow \mathrm{D} \\
\text { (months) }\end{array}$ & Clinical manifestations & $\begin{array}{l}\text { Current } \\
\text { 24-h UPO }\end{array}$ & ANCA & Biopsy & Therapy \\
\hline 23 & $\mathrm{~F}$ & 3 & $\begin{array}{l}\text { polyarthritis, hemoptysis, nephritic } \\
\text { syndrome, AKl, nephrotic syndrome }\end{array}$ & 4300 & c-Anca + 1:160 & $\begin{array}{l}\text { Kidney: pauci-immune } \\
\text { crescentic GN }\end{array}$ & CS, RTX \\
\hline 24 & $\mathrm{~F}$ & $\mathrm{n} / \mathrm{a}$ & sinusitis, anosmia, pulmonary fibrosis & $\mathrm{n} / \mathrm{a}$ & p-Anca + 1:640 & $\mathrm{n} / \mathrm{a}$ & CS, CFM \\
\hline 25 & $\mathrm{~F}$ & 3 & $\begin{array}{l}\text { Scleritis, purpura, polyarthritis, sinusitis, } \\
\text { Cushing's syndrome }\end{array}$ & $\mathrm{n} / \mathrm{a}$ & c-Anca + 1:80 & Skin: LCV & CS, MTX \\
\hline
\end{tabular}

$M$ male, $F$ female, $1 s t M \rightarrow D$ time in months from first manifestation of GPA to diagnosis, $A N C A$ antineutrophil cytoplasmic antibodies, UPO urine protein output, CFM cyclophosphamide, RTX rituximab, AZA azathioprine, CS corticosteroids, AKI acute kidney injury, IMGN immunoglobulin, PLASM plasmapheresis, GN glomerulonephritis, CKD chronic kidney disease, AVB atrioventricular block, CHF congestive heart failure, OP organizing pneumonia, $L C V$ leukocytoclastic vasculitis, Tu titer unavailable, FSGS focal segmental glomerulosclerosis

The observed frequency of cardiac involvement (16\%) matched the findings of other epidemiological studies but was lower than the frequency reported in case studies (25-46\%) [30]. CNS and gastrointestinal tract involvement was rare, as in most other studies $[13,29]$.

Two thirds (4/6) of our patients with 24-h proteinuria $>1 \mathrm{~g}$ at the time of diagnosis developed CKD after one year, with three patients requiring permanent dialysis. According to Neumann and coworkers, high levels of proteinuria at diagnosis in patients with ANCA-related glomerulonephritis may be predictive of poor renal prognosis [31]. The present study was limited by the unavailability of follow-up data to determine the frequency of development of CKD in patients with normal urine protein output (or $<1 \mathrm{~g}$ ) at the time of diagnosis. An expressive number of patients in our sample presented proteinuria in the nephrotic range (31\%). The degree of proteinuria in patients with GPA is most often subnephrotic [1]. High levels of proteinuria ( $>3 \mathrm{~g} /$ day) seem to be most common in patients who present later in the course of the disease and who have had previous necrotizing glomerulonephritis, leading to more focal and segmental glomerulosclerosis/fibrosis at the time of presentation. On the other hand, GPA patients with high levels of proteinuria may have a concurrent glomerular disease (e.g., membranous nephropathy) or an atypical histological pattern characterized by glomerular immune complex deposition [32, 33].

Patients with BVAS scores below and above the cohort average did not differ with regard to the frequency of renal involvement. Two patients who developed CKD had low BVAS scores $(<6)$ at diagnosis, suggesting factors other than kidney damage (possibly old age and late diagnosis and treatment) contributed to the poor prognosis in these cases.

Our ANCA positivity rate (87.5\%) was compatible with international reports (85\%) [4]. All patients presenting with the limited form of the disease were ANCA-positive. This is higher than previously published rates (up to $40 \%$ ANCA negativity) [4]. The fact that only 4 ANCA-positive patients were submitted to anti-PR3 ELISA (c-ANCA $n=3$;
p-ANCA $n=1$ ) was an unfortunate limiting factor in our clinical and epidemiological analysis of the anti-PR3 profile of GPA patients from Northeastern Brazil. The infrequent use of anti-PR3 ELISA in our sample prevented the adoption of GPA classification criteria based specifically on this assay (e.g., modified ACR) [34]. On the other hand, the use of the EMA algorithm offered the possibility of detecting ANCA by indirect immunofluorescence in settings with little or no access to anti-PR3 ELISA [19]. The EMA algorithm uses the 1990 criteria of the American College of Rheumatology (ACR) and the definition of the Chapel Hill Consensus Conference, in addition to the criteria of positive serology for ANCA [19, 35, 36].

ANCA-positive patients with high titers (1:640) (7/7) had low BVAS scores at diagnosis. While there is no consensus on the role of ANCA positivity in the prognosis of GPA patients, Finkielman and colleagues concluded that high ANCA titers were not predictive of disease activity, activity score or organ system affected at the time of recurrence [37].

The observed differences in the frequency of certain types of clinical manifestations (e.g., ENT and pulmonary) between Northeastern Brazil and other regions in the northern and southern hemispheres may be explained by the influence of environmental and latitudinal factors on clinical phenotype. One study showed an inverse relation between GPA incidence and the intensity of UV radiation at specific latitudes, implying Vitamin D synthesis is a major detemining factor of the observed gradients [12]. The fact that only $30 \%$ of our cohort was Caucasian (the remainder being of primarily indigenous race) should be taken into account when interpreting our findings.

The cohorts of most European studies consist almost exclusively of Caucasians $[9,38]$. Likewise, in a U.S. cohort study, over $90 \%$ of GPA patients were Caucasian while only $4 \%$ were Afro-American, Hispanic or Asian [1].

Improvement in kidney function after combination therapy with glucocorticoids and cyclophosphamide is well documented and is known to revert kidney damage in patients presenting with kidney failure [39]. In the present study, half the patients (4/8) treated endovenously 
with cyclophosphamide due to glomerulonephritis with creatinine clearance $<50 \mathrm{~mL} / \mathrm{min}$ at the time of diagnosis recovered kidney function. The other 4 developed CKD, 3 $(38 \% ; 3 / 8)$ of whom requiring permanent dialysis. Based on its successful use in ANCA-positive vasculitis and its greater likelihood of effectiveness against recurrence (compared to cyclophosphamide) and greater effectiveness at maintenance (compared to azathioprine), rituximab was administered to $32 \%$ of our patients, three quarters of whom presented renal involvement $[7,8,40]$.

The incidence of infection (including two cases in which infection contributed to the fatal outcome) was low in our cohort. Physicians in Northeastern Brazil are advised to include tuberculosis (a granulomatous disease highly prevalent in the region, with clinical manifestations not unlike those of GPA) in the differential diagnosis of GPA [41]. Despite the fact that some of our patients had a history of contact with, or treatment for, or chest $\mathrm{x}$-rays suggesting tuberculosis (e.g., cavitations and tree-in-bud), no active tuberculosis was observed. However, few patients in our cohort were submitted to the Mantoux test, especially those diagnosed in the five years preceding the study. This is partly due to a lack of supplies in the Brazilian public health care system (SUS) nationwide and partly due to limited access to testing for lymphocyte response against $M$. tuberculosis (interferon- $\gamma$ release assay). In addition, the frequency of ANCA positivity among patients diagnosed with tuberculosis can introduce a bias in the investigation of suspected cases $(10-33 \%$ of patients with this condition are ANCA-positive) [42].

Two early deaths (within one year of diagnosis) occurred during the study period (8\%). This is compatible with other studies reporting $6-11 \%$ early mortality from GPA [43, 44].

The study has a number of limitations as a result of the retrospective design, the inclusion of multiple centers and the extensive period sampled. Thus, the collected information was not always homogenous and complete. The lack of serial follow-up made it impossible to evaluate renal survival and compare clinical and prognostic factors. Possible loss to follow-up associated with difficulties in the diagnosis of the limited form of GPA and high mortality rates among patients with the diffuse form may have led to underreporting.

\section{Conclusions}

In this study from Northeastern Brazil, most patients were female, had the generalized form of the disease, presented nephritic syndrome during the evolution of the disease and were diagnosed late. Overall, the frequency of clinical manifestations was comparable to that reported in the international literature, with some differences in relation to the northern hemisphere (pulmonary and renal involvement) and the southern hemisphere
(ENT involvement), suggesting the existence of a Northeast Brazilian clinical and epidemiological profile and adding to our knowledge of this rare condition.

\section{Funding \\ The authors declare that there is no funding sources regarding the publication of this paper.}

\section{Authors' contributions}

FVAA collected the study data, analyzed the results and wrote the paper. FOL analyzed the results. JFC interpreted the patient data regarding the clinical and laboratory characteristics. ARSM analyzed the results and CEMR was a major contributor in writing the manuscript. All authors contributed to the preparation of this manuscript, read and approved the final manuscript.

\section{Ethics approval and consent to participate}

The study protocol was approved by the Research Ethics Committee of the University of Fortaleza (Unifor) and by the IRBs of the three participating referral centers.

\section{Competing interests}

The authors declare that they have no competing interests.

\section{Publisher's Note}

Springer Nature remains neutral with regard to jurisdictional claims in published maps and institutional affiliations.

\section{Author details}

${ }^{1}$ Post-Graduate Program in Medical Sciences, University of Fortaleza (UNIFOR), Fonseca Lobo 560 apto. 1202, Aldeota, Fortaleza, Ceará CEP 60175020 , Brazil. 'Division of Rheumatology, Federal University of Bahia, Salvador, Bahia, Brazil. ${ }^{3}$ Division of Rheumatology, University of Fortaleza (UNIFOR), Fortaleza, Brazil.

Received: 27 March 2018 Accepted: 31 May 2018

Published online: 28 June 2018

\section{References}

1. Hoffman GS, Kerr GS, Leavitt RY, Hallahan CW, Lebovics RS, Travis WD, et al. Wegener granulomatosis: an analysis of 158 patients. Ann Intern Med. 1992;116(6):488-98.

2. Hagen EC, Daha MR, Hermans J, Andrassy K, Csernok E, Gaskin G, et al. Diagnostic value of standardized assays for anti-neutrophil cytoplasmic antibodies in idiopathic systemic vasculitis. EC/BCR project for ANCA assay standardization. Kidney Int. 1998:53:743-53.

3. Hoffman GS, Specks U. Antineutrophil cytoplasmic antibodies. Arthritis Rheum. 1998;41:1521-37.

4. Koldingsnes W, Nossent $H$. Epidemiology of Wegener's granulomatosis in northern Norway. Arthritis Rheum. 2000:43:2481-7.

5. Falk RJ, Hogan S, Carey TS, Jennette JC. Clinical course of anti-neutrophil cytoplasmic autoantibody-associated glomerulonephritis and systemic vasculitis. The Glomerular Disease Collaborative Network. Ann Intern Med. 1990;113:656-63.

6. Nachman PH, Hogan SL, Jennette JC, Falk RJ. Treatment response and relapse in antineutrophil cytoplasmic autoantibody-associated microscopic polyangiitis and glomerulonephritis. J Am Soc Nephrol. 1996;7(1):33-9.

7. Besada E, Koldingsnes W, Nossent JC. Long-term efficacy and safety of pre-emptive maintenance therapy with rituximab in granulomatosis with polyangiitis: results from a single center. Rheumatology. 2013;52:2041-7.

8. Guillevin L, Pagnoux C, Karras A, Khouatra C, Aumaître O, Cohen P, et al. Rituximab versus azathioprine for maintenance in ANCA associated vasculitis. N Engl J Med. 2014;371:1772-80.

9. Watts R, Lane S, Scott D, Koldingsnes W, Nossent H, Gonzalez-gay M, et al. Epidemiology of vasculitis in Europe. Ann Rheum Dis. 2001;60:1156-7.

10. Catanoso M, Macchioni P, Boiardi L, Manenti L, Tumiati B, Cavazza A, et al. Epidemiology of granulomatosis with polyangiitis (Wegener's granulomatosis) in Northern Italy: a 15-year population-based study. Semin Arthritis Rheum. 2014;44:202-7. 
11. Gibson A, Stamp LK, Chapman PT, O'Donnel JL. The epidemiology of Wegener's granulomatosis and microscopic polyangiitis in a Southern hemisphere region. Rheumatology. 2006;45:624-8.

12. Gatenby PA, Lucas RM, Engelsen O, Ponsonby AL, Clements M. Antineutrophil cytoplasmic antibody-associated vasculitides: could geographic patterns be explained by ambient ultraviolet radiation? Arthritis Rheum. 2009;61:1417-24

13. Souza FHC, Halpern ASR, Barbas CSV, Shinjo SK. Wegener's granulomatosis: experience from a Brazilian tertiary center. Clin Rheumatol. 2010;29:855-60.

14. Rodrigues CEM, Callado MRM, Nobre CA, Moura FEA, Vieira RMRA, Albuquerque LAF, et al. Prevalência das manifestações clínicas iniciais da granulomatose de Wegener no Brasil - Relato de seis casos e revisão da literatura. Rev Bras Reumatol. 2010;50:150-64.

15. Cisternas M, Soto L, Jacobelli S, Marinovic MA, Vargas A, Sobarzo E, et al. Características clínicas de granulomatosis de Wegener y poliangeítis microscópica em pacientes chilenos. Rev Med Chil. 2005;133:273-8.

16. Gamron S, Muscellini EM, Onetti L, Menso E, Martelloto G, Barberis G, et al. Wegener's granulomatosis: its prevalence in a ten-year period in the rheumatology service of the Clinic Hospital, Cordoba, Argentina. Rev Fac Ciên Méd Univ Nac Cordoba. 2006;63:53-6.

17. Gamarra Al, Coral P, Quintana G, Toro CE, Flores LF, Matteson EL, et al. History of primary vasculitis in Latin America. Med Sci Monit. 2010;16(3):58-72.

18. Instituto Brasileiro de Geografia e Estatística (IBGE). Síntese Dados Demográficos Estados: Ceará, Brasil, 2016. Disponível em: <https:/cidades.ibge. gov.br/brasil/ce/fortaleza/panorama\&gt; . Acesso em 28 de dezembro de 2016.

19. Watts R, Lane S, Hanslik T, Hauser T, Hellmich B, Koldingsnes W, et al. Development and validation of a consensus methodology for the classification of the ANCA-associated vasculitides and polyarteritis nodosa for epidemiological studies. Ann Rheum Dis. 2007;66:222-7.

20. Mukhtyar C, Guillevin L, Cid MC, Dasgupta B, de Groot K, Gross W, European Vasculitis Study Group, et al. EULAR recommendations for the management of primary small and medium vessel vasculitis. Ann Rheum Dis. 2009;68:310-7.

21. Mukhtyar C, Lee R, Brown D, Carruthers D, Dasgupta B, Dubey S, et al. Modification and validation of the Birmingham Vasculitis activity score (version 3). Ann Rheum Dis. 2009;68:1827-32.

22. Levey AS, Stevens LA, Schmid CH, Zhang YL, Castro AF 3rd, Feldman HI, et al. A new equation to estimate glomerular filtration rate. Ann Intern Med. 2009;150:604-12.

23. Exley AR, Bacon PA, Luqmani RA, Kitas GD, Carruthers DM, Moots R, et al. Examination of disease severity in systemic vasculitis from the novel perspective of damage using the vasculitis damage index (VDI). Br J Rheumatol. 1998;37:57-63.

24. Hogan SL, Falk RJ, Chin H, Cai J, Jennette CE, Jennette JC, et al. Predictors of relapse and treatment resistance in antineutrophil cytoplasmic antibodyassociated small-vessel vasculitis. Ann Intern Med. 2005;143:621-31.

25. Fujimoto S, Watts RA, Kobayashi S, Suzuki K, Jayne DR, Scott DG, et al. Comparison of the epidemiology of anti-neutrophil cytoplasmic antibodyassociated vasculitis between Japan and the UK. Rheumatology. 2011;50:1916-20.

26. Ormerod AS, Cook MC. Epidemiology of primary systemic vasculitis in the Australian Capital Territory and south-eastern New South Wales. Intern Med J. 2008;38(11):816-23.

27. Gonzalez-Gay MA, Garcia-Porrua C, Guerrero J, Rodriguez-Ledo P, Llorca J. The epidemiology of the primary systemic vasculitides in Northwest Spain: implications of the Chapel Hill consensus conference definitions. Arthritis Care Res. 2003:49:388-93.

28. Watts RA, Lane SE, Bentham G, Scott DG. Epidemiology of systemic vasculitis: a ten-year study in the United Kingdom. Arthritis Rheum. 2000;43:414-9.

29. Reinhold-Keller E, Beuge N, Latza U, DeGroot K, Rudert H, Nolle B, et al. An interdisciplinary approach to the care of patients with Wegener's granulomatosis: long-term outcome in 155 patients. Arthritis Rheum. 2000;43:1021-32

30. Hazebroek MR, Kemna MJ, Schalla S, Wijk SS, Gerretsen SC, Dennert R, et al. Prevalence and prognostic relevance of cardiac involvement in ANCA-associated vasculitis: eosinophilic granulomatosis with polyangiitis and granulomatosis with polyangiitis. Int J Cardiol. 2015;199:170-9.

31. Neumann I, Kain R, Regele H, Soleiman A, Kandutsch S, Meisl FT. Histological and clinical predictors of early and late renal in ANCA-associated vasculitis. Nephrol Dial Transplant. 2005;20:96-104

32. Haas M, Eustace JA. Immune complex deposits in ANCA-associated crescentic glomerulonephritis: a study of 126 cases. Kidney Int. 2004;65(6):2145-52.
33. Neumann I, Regele H, Kain R, Birck R, Meisl FT. Glomerular immune deposits are associated with increased proteinuria in patients with ANCA-associated crescentic nephritis. Nephrol Dial Transplant. 2003;18(3):524-31.

34. The WGET Research Group. Design of the Wegener's granulomatosis Etanercept trial (WGET). Control Clin Trials. 2002;23:450-68.

35. Leavitt RY, Fauci AS, Bloch DA, Michel BA, Hunder GG, Arend WP, et al. The American College of Rheumatology 1990 criteria for the classification of Wegener's granulomatosis. Arthritis Rheum. 1990;33:1101-7.

36. Jennette JC, Falk RJ, Andrassy K, Bacon PA, Churg J, Gross WL, et al. Nomenclature of systemic vasculitides. Proposal of an international consensus conference. Arthritis Rheum. 1994:37:187-92.

37. Finkielman JD, Merkel PA, Schroeder D, Hoffman GS, Spiera R, St Clair EW, WGET Research Group, et al. Antiproteinase 3 antineutrophil cytoplasmic antibodies and disease activity in Wegener granulomatosis. Ann Intern Med. 2007:147:611-9.

38. Mahr A, Guillevin L, Poissonnet M, Aymé S. Prevalences of polyarteritis nodosa, microscopic polyangiitis, Wegener's granulomatosis, and ChurgStrauss syndrome in a French urban multiethnic population in 2000: a capture-recapture estimate. Arthritis Rheum. 2004;15(51):92-9.

39. Haubitz M, Schellong S, Göbel U, Schurek HJ, Schaumann D, Koch KM, et al. Intravenous pulse administration of cyclofosfamide versus daily oral treatment in patients with antineutrophil cytoplasmic antibody-associated vasculitis and renal involvement: a prospective, randomized study. Arthritis Rheum. 1998;41:1835-44.

40. Jones RB, Tervaert JW, Hauser T, Hauser T, Luqmani R, Morgan MD, et al. Rituximab versus cyclophosphamide in ANCA-associated renal vasculitis. New England J Med. 2010;363(3):211-20.

41. Ceará. Secretaria De Saúde Do Estado. Boletim epidemiológico da tuberculose no Ceará, março 2016. Brasil. Disponível em:< http://www. saude.ce.gov.br/index.php/boletins >. Acessado em 06 de março de 2016.

42. Teixeira L, Mahr A, Jaureguy F, Noel L-H, Nunes H, Lefort A, et al. Low seroprevalence and poor specificity of antineutrophil cytoplasmic antibodies in tuberculosis. Rheumatology. 2005;44:247-50.

43. Pettersson EE, Sundelin B, Heigl Z. Incidence and outcome of pauci-immune necrotizing and crescentic glomerulonephritis in adults. Clin Nephrol. 1995;43:141-9.

44. Westman KW, Bygren PG, Olsson H, Ranstam J, Wieslander J. Relapse rate, renal survival, and cancer morbidity in patients with Wegener's granulomatosis or microscopic polyangiitis with renal involvement. J Am Soc Nephrol. 1998;9:842-5.

\section{Ready to submit your research? Choose BMC and benefit from:}

- fast, convenient online submission

- thorough peer review by experienced researchers in your field

- rapid publication on acceptance

- support for research data, including large and complex data types

- gold Open Access which fosters wider collaboration and increased citations

- maximum visibility for your research: over $100 \mathrm{M}$ website views per year

At BMC, research is always in progress.

Learn more biomedcentral.com/submissions 